\title{
Menkes disease: importance of diagnosis with molecular analysis in the neonatal period
}

\author{
Larissa Sampalo de Athayde Costa ${ }^{1 *}$, Stephanie Pucci Pegler ${ }^{1}$, Rute Facchin Lellis², Vera Lúcia Jornada Krebs³, \\ Stephen Robertson ${ }^{4}$, Tim Morgan${ }^{4}$, Rachel Sayuri Honjo¹, Débora Romeo Bertola ${ }^{1}$, Chong Ae Kim ${ }^{1}$ \\ 'Genetics Unity, Instituto da Criança, Hospital das Clínicas, Faculdade de Medicina, Universidade de São Paulo (HC-FMUSP), São Paulo, SP, Brazil \\ 2Patology Department - Hospital Emilio Ribas, São Paulo, SP, Brazil \\ ${ }^{3}$ Neonatal Unity, HC-FMUSP, São Paulo, SP, Brazil \\ ${ }^{4}$ Department of Women and Children's Health, Dunedin School of Medicine, University of Otago, Dunedin, New Zeland
}

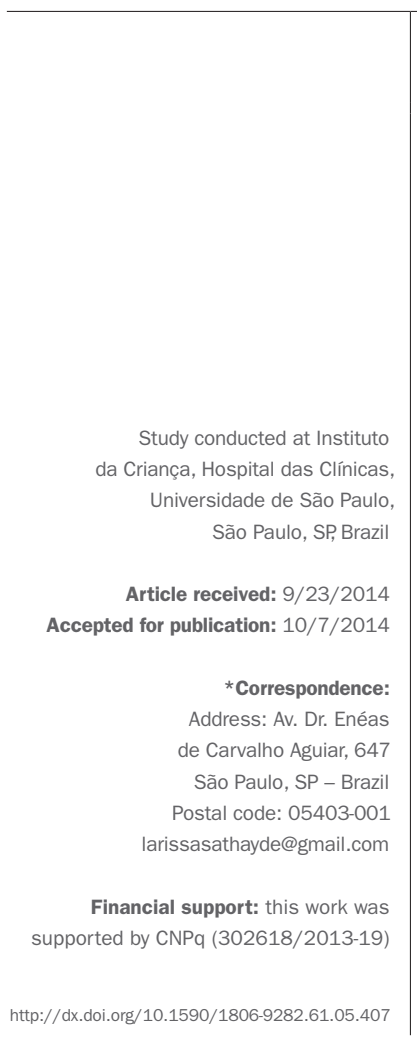

\section{SUMMARY}

\begin{abstract}
Menkes disease is a congenital disorder caused by changes in copper metabolism derived from mutations in the ATP7A gene. It is characterized by physical and neurological alterations. In the neonatal period, these alterations can be nonspecific, which makes early diagnosis a challenge. Diagnosis can be suspected when there are low levels of ceruloplasmin and serum copper. Molecular analysis confirms the diagnosis. Treatment is parenteral administration of copper histidine. We report a familial case with molecular confirmation. The proband had clinical and biochemical suspicious. Treatment with copper histidine was indicated, but initiated at the age of 2 months and 27 days only. He did not present improvements and died at 6 months. The mother became pregnant again, a male fetus was identified and copper histidine was manufactured during pregnancy. He was born healthy, biochemical markers were reduced and treatment was indicated. Molecular analysis was performed confirming mutation in both the mother and the proband, while the other son did not have mutation, so treatment was discontinued. We support the clinical relevance of molecular confirmation for the correct diagnosis and genetic counseling, once clinical findings in the neonatal period are nonspecific and early treatment with parenteral copper histidine must be indicated.
\end{abstract}

Keywords: copper, ceruloplasmin, Menkes Kinky hair syndrome.

\section{INTRODUCTION}

Menkes disease (MD) is a congenital X-linked disorder in copper metabolism. It is characterized by developmental delay, hypotonia, seizures, failure to thrive and hair anomalies. ${ }^{1}$

Early diagnosis is a challenge due to nonspecific clinical findings and unreliable biochemical markers. Biochemical markers used to reach diagnosis - low serum copper and low serum ceruloplasmin - are unreliable predictors in the neonatal period, due to low levels of these markers even in healthy newborns; clinical findings are nonspecific and may be misdiagnosed as neonatal sepsis. Once diagnosis is achieved, treatment is made with parental administration of copper histidine. Early treatment can modify disease progression and life expectancy. ${ }^{1,2}$
We describe a case of familial MD. Informed consent was obtained for publication.

\section{Case report}

Proband, the second child of a 23 year-old healthy mother, was born at term, by cesarean section, with a normal birth weight of $3,360 \mathrm{~g}\left(10-50^{\text {th }}\right.$ centile $)$ and length of 48 $\mathrm{cm}\left(10-50^{\text {th }}\right.$ centile), in good condition. He first attended our service at 1 months and 8 days with a history of eye twitching that began at 1 months and 2 days of age. The mother had already had a baby, to a different husband, who died at 3 months and 21 days with a clinical diagnosis of MD. The physical exam of our proband showed: weight of $4,080 \mathrm{~g}$ ( $15^{\text {th }}$ centile), length $52.8 \mathrm{~cm}$ 
( $15^{\text {th }}$ centile) and occipital frontal circumference (OFC) of $40 \mathrm{~cm}$ (>97 $97^{\text {th }}$ centile), steely, kinky, sparse hair, divergent strabismus of the left eye, pudgy cheeks and retromicrognathia (Figure 1).

Laboratorial exams showed very low serum ceruloplasmin $<2 \mathrm{mg} / \mathrm{dL}$ (reference range from $20-60 \mathrm{mg} / \mathrm{dL}$ ) and copper $<8 \mu \mathrm{g} / \mathrm{dL}$ (reference range from $70-160 \mu \mathrm{g} /$ $\mathrm{dL}$ ) confirming the clinical diagnosis of MD.

Treatment with copper histidine was indicated immediately but it was instituted only at age of 2 months and 27 days. The reason for delay was the time demanded for the preparation. Seizures were treated with clonazepam and phenobarbital. Electroencephalogram at 3 months presented diffuse disorganization with frequent paroxysms.

After 45 days of treatment, the levels of serum ceruloplasmin $(16 \mathrm{mg} / \mathrm{dL})$ and copper $(53.7 \mu \mathrm{g} / \mathrm{dL})$ were increased but remained below normal range. However, the patient showed no clinical improvement. At 6 months, neurological function deteriorated acutely and severely a subdural hematoma was detected and drainage was performed. Post-operatively, the patient developed pneumonia and died. No autopsy was performed.

Hair analysis of the mother and the proband were performed showing pili torti, trichorrhexis nodosa, and tricho-

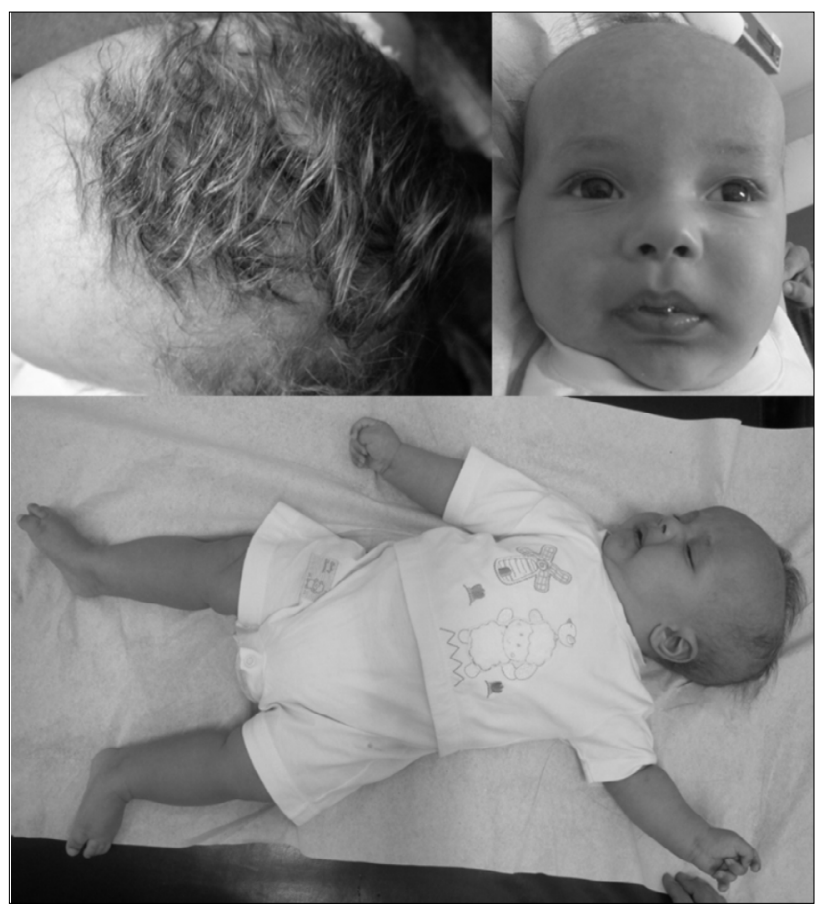

FIGURE 1 A: sparse, coarse and white hair; B: clinical appereance at age 4 months: divergent strabism, saggy cheeks; C: hypotonic posture. ptilosis. The proband presented these alterations in the entire hair, while the mother only in part of it (Figure 2).

Soon after, the mother had the fourth pregnancy with the same husband (Figure 3). Prenatal follow up was performed in our service and ultrasound showed a male fetus. The preparation of copper histidine was requested 2 months before birth. A male baby was born at 38 weeks, weight $3,530 \mathrm{~g}\left(50^{\text {th }}-90^{\text {th }}\right.$ centile $)$, length $50.5 \mathrm{~cm}\left(50^{\text {th }}-\right.$ $90^{\text {th }}$ centile), OFC of $36 \mathrm{~cm}$ ( $90^{\text {th }}$ centile). His physical exam was normal. Biochemical markers, collected at the first day, were reduced (ceruloplasmin $-7 \mathrm{mg} / \mathrm{dL}$ and serum copper - $26 \mu \mathrm{g} / \mathrm{dL}$ ). So, copper histidine was introduced since day 2. Serum levels of ceruloplasmin and copper increased after copper histidine therapy, but reached normal levels only after 2 months of treatment. The baby presented satisfactory growth and development.

Molecular study was performed: the proband was heterozygous for mutation in ATP7A gene (1668-1680 del, leading to p.ile556Metfs*11), the same mutation was found in his mother. The third son had no mutation. Treatment with copper histidine was discontinued after negative molecular test result in the third son.

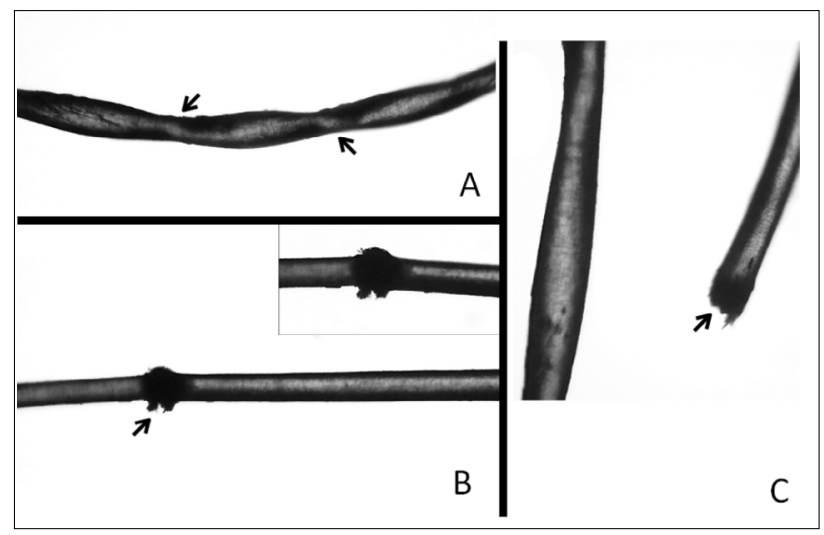

FIGURE 2 Microscopic hair analysis: A: pili torti; B:trichorrexis nodosa; C: trichoptilosi.

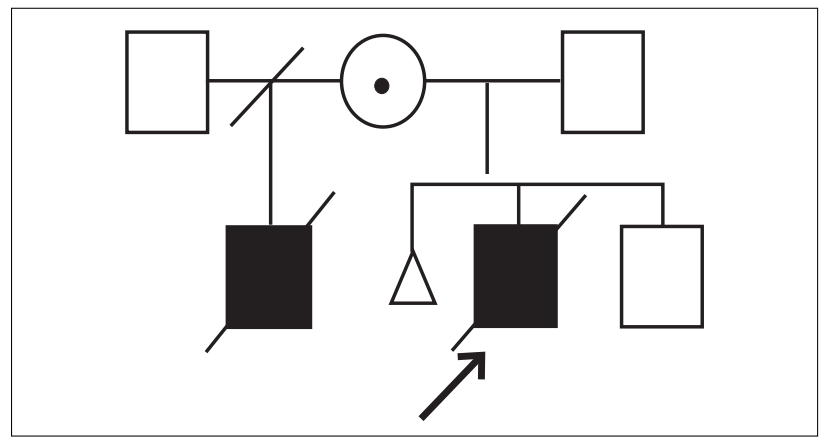

FIGURE 3 Heredogram. 


\section{Discussion}

$\mathrm{MD}$ is a congenital disorder of copper metabolism, resulting in copper deficiency. It is caused by mutation in the ATP7A gene. More than 350 different mutations have been described in this gene. ${ }^{3-6}$

ATP7A is present in almost all cell types and plays a role in intracellular copper transport. Copper is an essential mineral for some enzymes. Mutations in the ATP7A gene reduce copper absorption in intestinal cells, leading to copper deficiency, and reduce the activity of copperdependent enzymes. Copper also accumulates in the components of the blood-brain barrier and cannot be transported from the blood vessels to the neurons. ${ }^{3,7,8}$

Clinical features of MD occur due to copper-dependent enzymes deficiencies, leading to brain damage, seizures, hypotonia, arterial abnormalities, subdural hemorrhage, skin and joint laxity, abnormal hair (sparse, coarse and twisted with unusual colors such as white, silver and gray), hypothermia, diarrhea, failure to thrive, sagging cheeks and enlarged ears. ${ }^{3,7,8}$ Our patient had these clinical features corroborating clinical suspicious of MD.

Early diagnosis is a challenge, especially if it is the first case in the family. During the neonatal period, affected patients may present with nonspecific clinical findings, such as prolonged jaundice, hypothermia, hypoglycemia and feeding difficulties. ${ }^{2}$ The usual biochemical markers - low serum copper and ceruloplasmin - are uncertain in this period, due to low levels found even in healthy newborns. ${ }^{1}$

Light microscopy of hair shows pili torti, monilethrix, trichorrhexis nodosa. ${ }^{2,3}$ We performed hair analysis in our patient and his mother and the results were consistent with those described, showing hair alterations also in the carrier mother. Definitive diagnosis is confirmed by ATP7A mutation.

Treatment should begin as soon as possible with daily copper histidine subcutaneous injections, once intestinal absorption of copper is limited. Patients who began treatment within the neonatal period had better survival than infants who began later. When treatment is initiated in the neonatal period, neurological degeneration can be prevented in some patients, because the bloodbrain barrier is still immature. ${ }^{1,7}$ Copper histidine is not a routine medication in many hospitals, being a contributing factor for the delay in treatment. Unfortunately the prognosis is usually poor, with developmental delay and seizures.

\section{Conclusion}

Clinical findings and survival can be improved if treatment is initiated within the neonatal period. Nevertheless, diagnosis of MD is still a challenge, because of its initial nonspecific clinical findings, which can be mistaken for example for neonatal sepsis. Serum copper and ceruloplasmin levels can be decreased even in healthy infants, as seen in our patient. ${ }^{1,8}$ Molecular confirmation in our case was indispensable for the correct diagnosis of $\mathrm{MD}$, once biochemical markers are nonspecific of copper deficiency.

\section{Resumo}

Doença de Menkes: importância do diagnóstico com análise molecular no período neonatal

A doença de Menkes é causada por uma alteração genética no metabolismo do cobre, por mutações no gene ATP7A. Caracteriza-se por alterações neurológicas e no exame físico. No período neonatal, essas alterações podem ser inespecíficas, o que torna o diagnóstico precoce um desafio. $\mathrm{O}$ diagnóstico pode ser suspeitado quando há baixos níveis séricos de cobre e ceruloplasmina. A análise molecular confirma o diagnóstico, e o tratamento deve ser feito com histidina de cobre. Nós relatamos um caso familial de doença de Menkes. O probando apresentava quadro clínico e alterações bioquímicas compatíveis com a doença de Menkes, em consulta com 1 mês de vida. O tratamento foi indicado, mas apenas iniciado com 2 meses e 27 dias. Ele não apresentou melhora clínica e veio a óbito com 6 meses. A mãe teve uma nova gestação, foi identificado um feto do sexo masculino e foi solicitada a manipulação da histidina de cobre ainda durante a gestação. O bebê nasceu saudável, os marcadores bioquímicos estavam diminuídos e o tratamento com histidina de cobre foi indicado. Realizamos a análise molecular, que confirmou mutação no gene ATP7A na mãe e no probando; porém, o outro filho não apresentava mutação e o tratamento foi interrompido. Nós defendemos a importância clínica da confirmação molecular para o correto diagnóstico e o aconselhamento genético da doença de Menkes, uma vez que os achados clínicos e as alterações bioquímicas no período neonatal são inespecíficos, e o tratamento com histidina de cobre parenteral deve ser rapidamente instituído.

Palavras-chave: cobre, ceruloplasmina, síndrome dos cabelos torcidos. 


\section{REFERENCES}

1. Kaler SG, Holmes CS, Goldstein DS, Tang J, Godwin SC, Donsante A, et al. Neonatal diagnosis and treatment of Menkes disease. N Engl J Med. 2008; 358:605-14.

2. Tumer Z, Moller LB. Menkes disease. Eur J Hum Genet. 2010; 18:511-8.

3. Kodama H, Fujisawa C, Bhadhprasit W. Inherited copper transport disorders: biochemical mechanisms, diagnosis, and treatment. Current Drug Metabolism. 2012; 13:237-50

4. Moller LB, Mogensen M, Horn N. Molecular diagnosis of Menkes disease: genotype-phenotype correlation. Biochimie. 2009; 91:1273-7.
5. Prasad AN, Levin S, Rupar CA, Prasad C. Menkes disease and infantile epilepsy. Brain Dev. 2011;33:866-76.

6. Menkes JH, Alter M, Steigleder GK, Weakley DR, Sung JH. A sex-linked recessive disorder with retardation of growth, peculiar hair and focal cerebral and cerebellar degeneration. Pediatrics. 1962; 29:764-79.

7. Kodama H, Fujisawa C, Bhadhprasit W. Pathology, clinical features and treatments of congenital copper metabolic disorders - Focus on neurologic aspects. Brain Dev. 2011; 33:243-51.

8. Kaller SG. Inborn errors of copper metabolism. In: Dulac O, Lassonde M, Sarnat HB (eds.). Handbook of clinical neurology. v.113. Amsterdam: Elsevier, 2013. p.1745-54. 